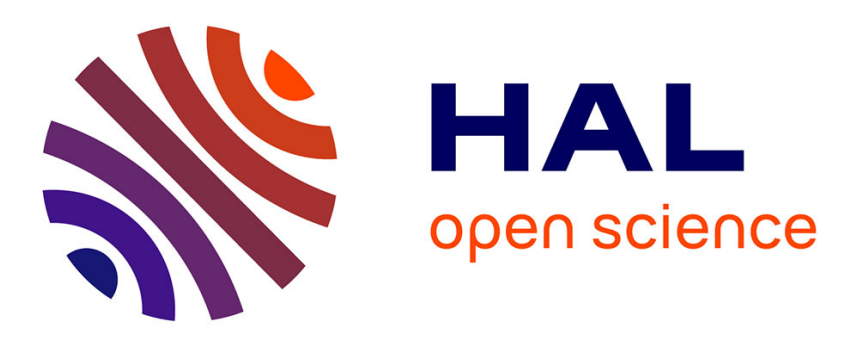

\title{
Dextran sulfate enhances the level of an oxidative DNA damage biomarker, 8-oxo-7,8-dihydro-2'-deoxyguanosine, in rat colonic mucosa.
}

\author{
D. Tardieu, J. P. Jaeg, J. Cadet, E. Embvani, D. E. Corpet, C. Petit
}

\section{- To cite this version:}

D. Tardieu, J. P. Jaeg, J. Cadet, E. Embvani, D. E. Corpet, et al.. Dextran sulfate enhances the level of an oxidative DNA damage biomarker, 8-oxo-7,8-dihydro-2'-deoxyguanosine, in rat colonic mucosa..

Cancer Letters, 1998, 134 (1), pp.1-5. hal-00411067

\section{HAL Id: hal-00411067 \\ https://hal.science/hal-00411067}

Submitted on 25 Aug 2009

HAL is a multi-disciplinary open access archive for the deposit and dissemination of scientific research documents, whether they are published or not. The documents may come from teaching and research institutions in France or abroad, or from public or private research centers.
L'archive ouverte pluridisciplinaire HAL, est destinée au dépôt et à la diffusion de documents scientifiques de niveau recherche, publiés ou non, émanant des établissements d'enseignement et de recherche français ou étrangers, des laboratoires publics ou privés. 


\title{
Dextran sulfate enhances the level of an oxidative DNA damage biomarker, 8-0xo-7,8-dihydro-2 0-deoxyguanosine, in rat colonic mucosa
}

\author{
D. Tardieu ${ }^{\text {a }}$, J.P. Jaeg ${ }^{\text {a }}$, J. Cadet ${ }^{\text {b }}$, E. Embvani ${ }^{\text {a }}$, D.E. Corpet ${ }^{\text {a }}$, C. Petit ${ }^{\text {a }}$ \\ ${ }^{a}$ Ecole Nationale Vétérinaire, Sécurité et Hygiène des Aliments, Institut National de la Recherche \\ Agronomique, $23 \mathrm{Ch}$. des Capelles, 31076 Toulouse Cedex, France \\ ${ }^{\mathrm{ab}}$ Département de Recherche Fondamentale sur la Matière Condensée, SCIB/LAN, CEA/Grenoble, F-38054 \\ Grenoble Cedex 9, France
}

\begin{abstract}
Dextran sodium sulfate (DSS) given in drinking water can induce colonic Inflammation and produce colorectal tumors in rodents, although it is not directly genotoxic. The hypothesis that DSS can produce free radicals and induce oxidative DNA damage in colonic mucosa has been tested. In rats fed for 2 days with water containing $3 \%$ and $6 \%$ DSS, colonic Inflammation manifestations were recorded and 8-oxo-7,8-dihydro-2 0deoxyguanosine (8-oxodGuo), a major biomarker of oxidative DNA damage, was assayed in colonic mucosa. As compared with control rats given pure water, inflammatory manifestations were seen in rats given DSS. At the same time, 8-oxodGuo levels in colonic mucosa were doubled $(\mathrm{P}<0.001)$. These results suggest that formation of oxidative DNA damage in colonic mucosa depends on inflammation and maybe on the production of reactive oxygen species. This study shows that DSS can induce oxidative DNA damage within only 2 days, which could explain in part its carcinogenic properties.
\end{abstract}

Keywords: Oxidative DNA damage; 8-OxodGuo; Ulcerative colitis; Free radicals; Colonic inflammation

\section{Introduction}

Dextran sodium sulfate (DSS), a mixture of polysaccharides of different molecular weights differing in their degree of sulfate substitution [20], given per os to rodents induces an Inflammation of the colonic mucosa. These rodents are relevant experimental models for ulcerative colitis [21]. In humans, long standing ulcerative colitis and Crohn's disease are generally described as important risk factors for colorectal cancer development [13], which is the second leading cause of death from cancer in Western countries including North America [24]. In rodents, DSS induces colonic tumors but the carcinogenic mechanisms are not known because DSS is not directly mutagenic $[14,25]$. Inflammation via repeated epithelial necrosis and regeneration and/or via DNA alterations might explain the initiation of the carcinogenic process [22].

8-Oxo-7,8-dihydro-2 0-deoxyguanosine (8-oxod- Guo), as a result of hydroxylation of the guanine base residues in DNA, is considered as an important biomarker of oxidative DNA damage. 8-OxodGuo has been implicated in mutagenic and carcinogenic processes $[6,17,18]$. Other investigations have provided strong indirect evidence supporting the role of oxidative stress in carcinogenesis [1]. We make the hypothesis that DSS can produce free radicals, likely via Inflammation, and induce oxidative DNA damage in colonic mucosa that may explain the carcinogenic activity of a non-genotoxic compound.

By measuring 8-oxodGuo with HPLC and electrochemical detection, the present study investigated DNA damage in the colonic mucosa of rats given DSS for only 2 days and shows for the first time that oxidative DNA damage may be a consequence of colonic Inflammation.

\section{Materials and methods}

\subsection{Chemicals, DNA extraction, reagents}


DSS (MW $40 \mathrm{kDa}$ ) was obtained from ICN Biomedicals (Aurora, OH). 8-OxodGuo, dGuo, nuclease P1 (EC 3.1.30.1) and alkaline phosphatase (EC 3.1.3.2.2.1) were obtained from Sigma (St. Louis, MO). A DNA extraction kit (Quiagen, Courtaboeuf, France) was used. Methanol, ethanol, chloroform of HPLC grade and buffer components were purchased from Merck (Darmstadt, Germany).

\subsection{Animal treatments and analytical procedures}

Thirty 4-week-old female Fisher 344 rats (Iffa credo, Lyon, France) were acclimatized for 5 days to the animal colony, fed a low fat rodent chow (UAR, Villemoisson, France) ad libitum and randomized to three groups of 10 rats. A control group was given distilled drinking water ad libitum. Two experimental groups received $3 \%$ or $6 \%$ DSS in distilled drinking water for 2 days.

Body weight and water intake were recorded daily. Diarrhea was estimated by the ratio of fecal wet weight/dry weight. Fecal occult blood was assayed with the Hemoccult II test (SKD, Gagny, France); the intensity of the color showing occult blood was graded on a scale between 0 and 3 . Animals were sacrificed 2 days after the start of DSS administration by cervical dislocation. The colon was dissected between the ileocecal junction and the proximal rectum. The colon was placed on a non-absorbent surface, measured and flushed with cold $0.9 \% \mathrm{NaCl}$ $\left(4^{\circ} \mathrm{C}\right)$. The colon was opened longitudinally and the mucosa was removed by scratching the distal surface with a lancet blade ( $5 \mathrm{~cm}$ at the rectal end). The samples were rinsed with $0.9 \% \mathrm{NaCl}$ and centrifuged at $3000 £ \mathrm{~g}$ for 10 $\mathrm{min}$. The pellets were immediately frozen at $-80^{\circ} \mathrm{C}$ until 8-oxodGuo was assayed within the next 2 days.

\subsection{DNA extraction and 8-oxodGuo assay}

The Quiagen genomic DNA kit was used to extract DNA at an ambient temperature from cellular pellets. After homogenization with a Potter homogenizer, the samples were lysed with proteinase $\mathrm{K}(1 \mathrm{mg} / \mathrm{ml})$ at $50^{\circ} \mathrm{C}$ for $2 \mathrm{~h}$ in buffer G2 (800 mM GuHCl, $30 \mathrm{mM}$ EDTA, $30 \mathrm{mM}$ Tris $\pm \mathrm{HCl}, 5 \%$ Tween- 20 and $0.5 \%$ Triton X-100 $(\mathrm{pH}$ 8.0)). The lysates $(10 \mathrm{ml})$ were then applied on the equilibrated $(750 \mathrm{mM} \mathrm{NaCl}, 50 \mathrm{mM}$ MOPS and $0.15 \%$ Triton $\mathrm{X}-100(\mathrm{pH} 7.0))$ Quiagen genomic tips. After washing the tips with QC buffer (1.0 M NaCl, $50 \mathrm{mM}$ MOPS and $15 \%$ ethanol ( $\mathrm{pH} 7.0)$ ), the purified genomic DNA was eluted with QF buffer (1.25 M NaCl, $50 \mathrm{mM}$ Tris $\pm \mathrm{HCl}$ and $15 \%$ ethanol ( $\mathrm{pH} 8.5)$ ). The DNA was precipitated with 2- propanol, washed with $70 \%$ ethanol at $-20^{\circ} \mathrm{C}$, airdried and diluted in $100 \mathrm{ml}$ of sterile water before analysis.

DNA in aqueous solution was hydrolyzed to nucleotides by 10 units of nuclease $\mathrm{P} 1$ for $2 \mathrm{~h}$ at $37^{\circ} \mathrm{C}$ in acetate buffer (pH 5.3) according to the method of Floyd [9]. Dephosphorylation was achieved by incubation with 2 units of alkaline phosphatase in Tris $\pm \mathrm{HCl}$ buffer $\left(\mathrm{pH} \mathrm{8.0)}\right.$ for $1 \mathrm{~h}$ at $37^{\circ} \mathrm{C}$. Proteins were precipitated with chloroform and the aqueous layer was analyzed by HPLC with electrochemical (EC) detection.

The HPLC system consisted of a pump M 2200 (Bischoff, Leonberg, Germany) and an autosampler 738 (ICS, Toulouse, France) equipped with a 12:5 $£$ 4:6 mm Spherisorb ODS 2 column (Bischoff). A detector focus (Spectra-Physics, Les Ulis, France) set at $280 \mathrm{~nm}$ and an EC detector coulochem II (ESA, Chelmsford, MA) set at 1200 and $1400 \mathrm{mV}$ for electrodes 1 and 2, respectively, monitored unmodified and modified nucleosides. An isocratic eluent, $50 \mathrm{mM}$ phosphate buffer ( $\mathrm{pH} 5.5$ ) containing $10 \%$ methanol, was used at a flow rate of 1.0 $\mathrm{ml} / \mathrm{min}$. The PIC 3 software (ICS) permitted quantification 2 D. Tardieu et al. / Cancer Letters 134 (1998) $1 \pm 5$ of DNA oxidative damage using calibration curves obtained with authentic standards.

\subsection{Statistics}

Data were first analyzed by one-way analysis of variance and then Student's t-test was used to compare experimental and control group means. Scores for fecal occult blood were analyzed by the non parametric Kruskal \pm Wallis test.

\section{Results}

As shown in Table 1, rats given 6\%DSS in drinking water for 2 days gained less weight $(\mathrm{P}<0.05)$ and drank significantly more water than controls $(\mathrm{P}<0.001)$.

\subsection{Colonic Inflammation manifestations}


According to Axelsson et al. [2], colonic Inflammation could be simply assessed by diarrhea, colon length and rectal bleeding. Visual inspection of feces revealed obvious diarrhea in rats given $6 \%$ DSS in drinking water. A $55 \%$ increase in the fecal wet/dry ratio was observed in rats given $6 \%$ DSS compared to control rats given pure water $(\mathrm{P}<0.05)$. This increase was not seen in rats given $3 \%$ DSS (Table 1). No significant difference in colon length was found between the three groups of rats (data not shown). No blood could be detected by visual inspection of feces. Fecal occult blood was induced by DSS in a dose-dependant manner and significant differences were found between groups (Table 1).

Table 1. Effects of the administration of dextran sulfate sodium (DSS) via drinking water for 2 days in F344 rats

\begin{tabular}{llllll}
\hline \% DSS in water & $\begin{array}{l}\text { No. of } \\
\text { rats }\end{array}$ & $\begin{array}{l}\text { Body } \\
\text { weight gain } \\
\text { (g/day) }\end{array}$ & $\begin{array}{l}\text { Water } \\
\text { intake }(\mathrm{ml} / \\
\text { day) }\end{array}$ & $\begin{array}{l}\text { Diarrhoea } \\
\text { (wet/dry } \\
\text { weight } \\
\text { ratio) }\end{array}$ & $\begin{array}{l}\text { Faecal } \\
\text { occult blood } \\
\text { score }\end{array}$ \\
\hline 0 & 10 & $6.8 \pm 2.9^{\mathrm{b}}$ & $9.2 \pm 0.5$ & $3.6 \pm 0.8$ & $0.0 \pm 0.0$ \\
3 & 10 & $6.6 \pm 1.9$ & $10.6 \pm 0.4^{* *}$ & $3.3 \pm 0.7$ & $1.0 \pm 0.7^{*}$ \\
6 & 10 & $4.4 \pm 2.4^{*}$ & $11.2 \pm 0.5^{* *}$ & $5.5 \pm 2.7^{*}$ & $2.8 \pm 1.0^{* *}$ \\
ANOVA $P$-value $^{\mathrm{a}}$ & & 0.05 & $<0.0001$ & 0.01 & $<0.0001$
\end{tabular}

a P-values were calculated by parametric ANOVA, except for fecal occult blood scores.

$\mathrm{b}$ Data are the mean \pm standard deviation. $* \mathrm{P}<0.05$, $* * \mathrm{P}<0.001$ when compared with controls given $0 \% \mathrm{DSS}$.

\subsection{8-Oxo-7,8-dihydro-2 0-deoxyguanosine levels}

In a pilot study, three Wistar rats were given 5\% DSS in drinking water for 2 days. The ratio 8-oxod- Guo/dGuo was doubled compared to controls given pure water (data not shown).

Fig. 1 shows the effect of DSS on the 8-oxodGuo level in Fisher 344 rats. This level in the control group ranged from 1.2 to $4.6 \mathrm{~mol}$ of 8 -oxodGuo per $105 \mathrm{~mol}$ of dGuo. The levels of 8-oxodGuo in the mucosa of rats given $3 \%$ and $6 \%$ DSS ranged from 2.5 to $7.1 \mathrm{~mol}$ per $105 \mathrm{~mol}$ of dGuo and from 2.5 to $8.0 \mathrm{~mol}$ per $105 \mathrm{~mol}$ of dGuo, respectively (Fig. 1).

The means of 8-oxodGuo levels in rats treated by DSS were higher than those of the control and the differences were statistically significant ( $\mathrm{P}<0.014$ for $3 \% \mathrm{DSS}$ and $\mathrm{P}<0.001$ for $6 \% \mathrm{DSS}$ ). The difference between rats given $3 \%$ and $6 \%$ DSS was not significant $(\mathrm{P}=0.21)$ 


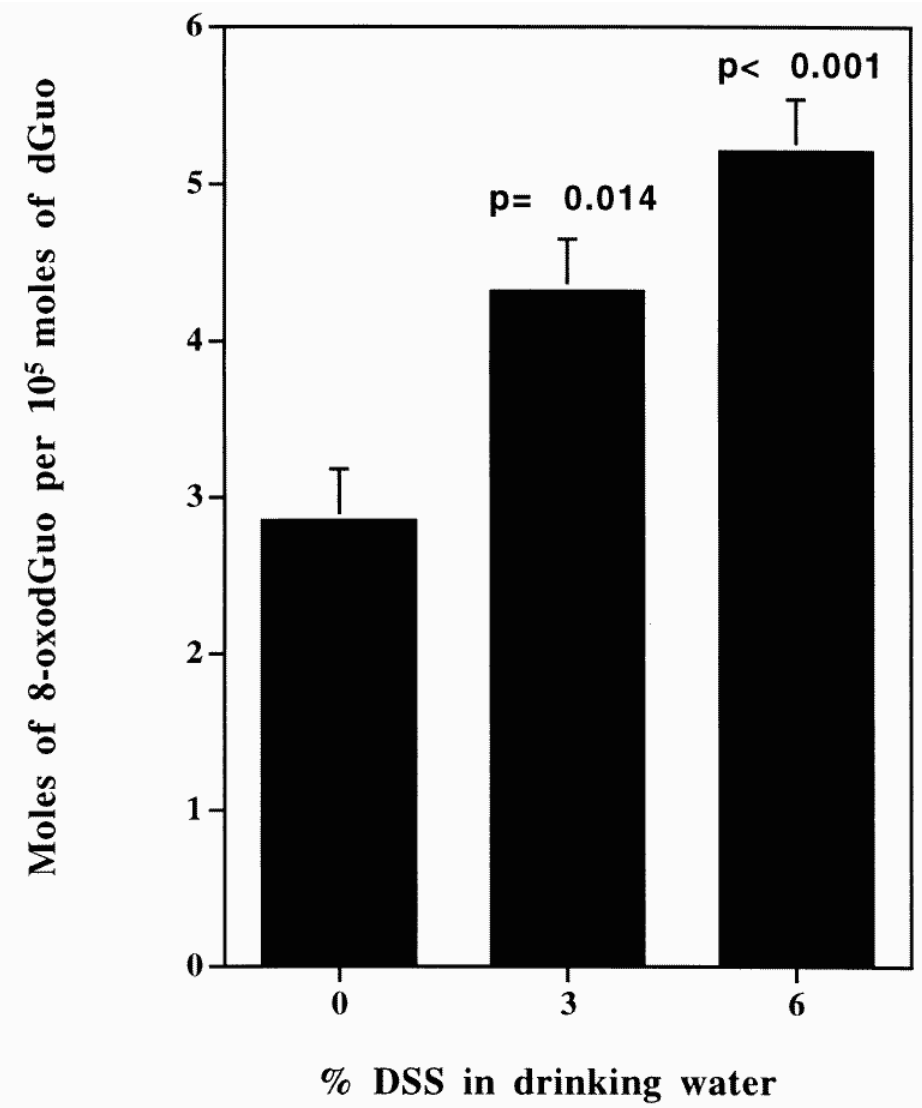

Fig. 1. 8-OxodGuo levels in colonic mucosa DNA after administration of dextran sulfate sodium (DSS) via drinking water for 2 days in F344 rats. Data are the mean \pm standard deviation of 10 independent measures from 10 rats. Treated groups are compared to $0 \%$ DSS controls by t-test and two-way P-values.

\section{Discussion}

This work shows for the first time that in rats fed with DSS, the level of 8-oxodGuo in DNA of colonic mucosa increased two-fold after 2 days. 8-OxodGuo is considered as a major class of oxidative DNA damage, which is involved in mutagenic and carcinogenic processes. Furthermore, high levels of 8-oxodGuo have been detected in target organs of various carcinogens [9,16,19,23]. Relationships between oxidative DNA damage and Inflammation have previously been convincingly demonstrated in chronic diseases like hepatitis [11] or atrophic gastritis caused by Helicobacter pylori [4].

The amount of 8-oxodGuo tended to increase with the concentration of DSS but there was no significant difference between rats given $3 \%$ and $6 \%$ DSS. Thus, it is conceivable that the $3 \%$ regimen might have saturated the oxidation process, while the $6 \%$ DSS dose might have been too toxic to the mucosa, leaving few living cells. Indeed DNA can be extracted and measured for oxidation only from living cells. DSS (3\% and 6\%) in drinking water induced a slowing down of the body weight gains after 2 days and also induced diarrhea. The subsequent loss of water may explain both why rats given DSS did not grow as rapidly as controls and the increased water consumption. Also rectal bleeding was induced by $3 \%$ and $6 \%$ DSS. This would confirm that Inflammation was effective in a short time. This is consistent with the experiments of Axelsson et al. [2] which induced moderate Inflammation (demonstrated by histological analysis) in mice with $1.25 \%$ DSS within 1 week. Reactive oxygen species (ROS) such as superoxide anion and other oxygenated radicals are implicated in the Inflammatory reaction $[3,7,10]$. We speculate that DSS provokes an Inflammation of the colon with the generation of ROS. Indeed, ROS have been demonstrated to induce DNA damage [12] and it has been speculated that this DNA damage could lead to carcinogenesis [5,26].

Thus, it is conceivable that chronic subclinical colon Inflammation is involved in the high frequency of colon cancer observed in Western countries. Interestingly, most of the protective effects of the so-called Mediterranean diet against cancer might be related to antioxidants and free radical scavengers $[8,15]$. 
This study has permitted the rapid ( 2 days) recording of early oxidative damage in vivo which may eventually lead to colon carcinogenesis. Moreover, this protocol may be used to test the effect of xenobiotics or of diets on the oxidative DNA damage process and to determine their antioxidant properties. Further investigations on this point are in progress in our laboratory.

\section{Acknowledgements}

We thank S. Boiteux, T. Douki and J.L. Ravanat for their help and advice in 8-oxodGuo measurements, S. Taché and G. Peiffer for the rat treatments and sacrifice and R. Gazel and A.M. Debrusse for taking care of the rats. The study was supported by the Direction Générale de l'Enseignement et de la Recherche, du Ministère de l'Agriculture (France).

\section{References}

[1] B.N. Ames, L.S. Gold, The causes and prevention of cancer: gaining perspective, Environ. Health Perspect. 105 (Suppl. 4) (1997) 865-872.

[2] L.-G. Axelsson, E. Landstrom, T.J. Goldschmidt, A. Gronberg, A.-C. Bylund-Fellenius, Dextran sulfate sodium (DSS) induced experimental colitis in immunodeficient mice. Effects in CD41, Inflamm. Res. 45 (4) (1996) 181-191.

[3] B.M. Babior, R.S. Kipnes, J.T. Carnutte, Biological defense mechanisms. The production by leukocytes of superoxide, a potential bactericidal agent, J. Clin. Invest. 52 (1973) 741- 744.

[4] S.C. Baik, H.S. Youn, M.H. Chung, W.K. Lee, M.J. Cho, G.H. Ko, C.K. Park, H. Kasai, K.H. Rhee, Increased oxidative DNA in Helicobacter pylori-infected human gastric mucosa, Cancer Res. 56 (1996) 12791282.

[5] P.A. Cerrutti, Prooxidant states and tumor promotion, Science 227 (1985) 375-381.

[6] K.C. Cheng, D.S. Cahill, H. Kasai, S. Nishimura, L.A. Loeb, 8-Hydroxyguanine, an abundant form of oxydative DNA damage, causes G-T and A-C substitutions, J. Biol. Chem. 267 (1992) 166-172.

[7] J.T. Curnutte, B.M. Babior, Chronic granulomatous disease, Adv. Hum. Genet. 16 (1987) 229-245.

[8] A. Ferro-Luzzi, F. Branca, Mediterranean diet, Italian style: prototype of healthy diet, Am. J. Clin. Nutr. 61 (1995) S1338-S1345.

[9] R.A. Floyd, The role of 8-hydroxyguanine in carcinogenesis, Carcinogenesis 11 (1990) 1447-1450.

[10] M.B. Grisham, Oxidants and free radicals in Inflammatory bowel disease, Lancet 344 (1994) 859-861.

[11] T.M. Hagen, S. Huang, J. Curnutte, P. Fowler, V. Martinez, C.M. Wehr, B.N. Ames, F.V. Chisari, Extensive oxidative DNA damage in hepatocytes of transgenic mice with chronic active hepatitis destined to develop hepatocellular carcinoma, Proc. Natl. Acad. Sci. USA 91 (1994) 12808-12812.

[12] B. Halliwell, J.M.C. Gutteridge, Free Radicals in Biology and Medicine, second ed., Clarendon Press, Oxford, 1989

[13] J.M. Hinton, Risk of malignant change in ulcerative colitis, Gut 7 (1966) 427-432.

[14] T. Ishioka, N. Kuwabara, Y. Oohasi, K. Wakabayashi, Induction of colorectal tumors in rats by sulfated polysaccharides, CRC Crit. Rev. Toxicol. 17 (1987) 215-244.

[15] M.S. Jang, L. Cai, G.O. Udeani, K.V. Slowing, C.F. Thomas, C.W.W. Beecher, H.H.S. Fong, N.R. Farnsworth, A.D. Kinghorn, R.G. Metha, R.C. Moon, J.M. Pezzutot, Cancer chemopreventive activity of resveratrol, a natural product derived from grapes, Science 275 (1997) 218-220. 
[16] H. Kasai, S. Nishimura, Y. Kurokawa, Y. Hayashi, Oral administration of the renal carcinogen, potassium bromate, specifically produces 8-hydroxydeoxyguanosine in rat target organ DNA, Carcinogenesis 8 (1987) 1959-1961.

[17] M. Moriya, Single-stranded shuttle phasemid for mutagenesis studies in mammalian cells. 8-Oxoguanine in DNA induces targeted G.C-T.A transversions in simian kidney cells, Proc. Natl. Acad. Sci. USA 90 (1993) $1122-1126$.

[18] M. Moriya, C. Ou, V. Bodepudi, F. Johnson, M. Takeshita, A.P. Grollman, Site-specific mutagenesis using a gapped duplex vector: a study of translesion synthesis past 8-oxodeoxyguanosine in E. coli, Mutat. Res. 254 (1991) 281-288.

[19] M. Nagashima, H. Kasai, J. Yokota, Y. Nagamachi, T. Ichinose, M. Sagai, Formation of an oxidative DNA damage, 8- hydroxydeoxyguanosine, in mouse lung DNA after intratracheal instillation of diesel exhaust particles and effects of high dietary fat beta-carotene on this process, Carcinogenesis 16 (1995) 1441-1445.

[20] K. Nilsson, G. Soderlund, Clinical dextrans. Specifications and quality of preparations on the market, Acta Pharm. Suec. 15 (1978) 439-454.

[21] I. Okayasu, S. Hatakeyama, M. Yamada, T. Ohkusa, Y. Ingaki, R. Nakaya, A novel method in the induction of reliable experimental acute and chronic ulcerative colitis in mice, Gastroenterology 98 (1990) 694-702.

[22] E. Shacter, E.J. Beecham, J.M. Covey, K.W. Kohn, M. Potter, Activated neutrophyls induce prolonged DNA damage in neighboring cells, Carcinogenesis 9 (1988) 2297-2304.

[23] H.M. Shen, C.N. Ong, B.L. Lee, C.Y. Shi, Aflatoxin B1- induced 8-hydroxydeoxyguanosine formation in rat hepatic DNA, Carcinogenesis 16 (1995) 419-422.

[24] W.E. Smalley, R.N. Dubois, Colorectal cancer and nonsteroidal anti-Inflammatory drugs, Adv. Pharmacol. 39 (1997) 1-20.

[25] G.H. Therkelsen, in: R.L. Whistler, J.N. BeMiller (Eds.), Polysaccharides and Their Derivatives, third ed., Academic Press, San Diego, CA, 1992, pp. 146-180.

[26] W. Troll, R. Wiesner, The role of oxygen radicals as a possible mechanism of tumor promotion, Annu. Rev. Pharmacol. Toxicol. 25 (1985) 509-528. 